\title{
CLTCL1 wt Allele
}

National Cancer Institute

\section{Source}

National Cancer Institute. CLTCL1 wt Allele. NCI Thesaurus. Code C97416.

Human CLTCL1 wild-type allele is located in the vicinity of 22q11.2 and is approximately $112 \mathrm{~kb}$ in length. This allele, which encodes clathrin heavy chain 2 protein, plays a role in receptor-mediated endocytosis and cellular vesicle transport. Chromosomal aberrations involving this gene are associated with meningioma, DiGeorge syndrome, and velocardio-facial syndrome. 